\title{
An Uncanny Myth of Ireland: The Spectralisation of Cuchulain's Body in W. B. Yeats's Plays
}

\section{Zsuzsanna Balázs}

\section{Q OpenEdition \\ 1 Journals}

\section{Electronic version}

URL: http://journals.openedition.org/etudesirlandaises/5102

DOI: 10.4000/etudesirlandaises.5102

ISSN: 2259-8863

\section{Publisher}

Presses universitaires de Rennes

\section{Printed version}

Date of publication: 29 June 2017

Number of pages: 61-75

ISBN: 978-2-7535-5495-5

ISSN: 0183-973X

\section{Electronic reference}

Zsuzsanna Balázs, " An Uncanny Myth of Ireland: The Spectralisation of Cuchulain's Body in W. B. Yeats's Plays », Études irlandaises [Online], 42-1 | 2017, Online since 29 June 2019, connection on 07 September 2019. URL : http://journals.openedition.org/etudesirlandaises/5102 ; DOI : 10.4000/ etudesirlandaises.5102 


\title{
An Uncanny Myth of Ireland: The Spectralisation of Cuchulain's Body in W. B. Yeats's Plays
}

\author{
Zsuzsanna BaLÁzs \\ Pázmány Péter Catholic University, Budapest
}

\begin{abstract}
This paper addresses William Butler Yeats's dramatisation of his life-long interest in the invisible realm and an ideal Irish aristocracy in his five Cuchulain plays. I wish to illustrate how Yeats expresses his increasing ambiguities over the cultural and political capacities of the AngloIrish Protestant Ascendancy through the changes of the Irish warrior-hero Cuchulain's body and the growing predominance and influence of the spectral world on his bodily integrity. Even though Cuchulain is generally referred to as the embodiment of Irish national identity and the ideal aristocrat in Yeats's works, I would like to point out those aspects of his Cuchulain-story, where this idealised narrative of Ireland and the Ascendancy seems to be challenged.

Keywords: W. B. Yeats, Anglo-Irish Ascendancy, Cuchulain, spectrality, the uncanny, modern Irish theatre, heroism, tragic joy, gaze.
\end{abstract}

\section{Résumé}

Le présent article aborde la façon dont W.B. Yeats met en scène son obsession d'un univers invisible et d'une aristocratie idéale dans ses cinq pièces consacrées au héros-guerrier Cuchulain. Je souhaite démontrer comment Yeats exprime sa perception de plus en plus ambiguë des capacités culturelles et politiques de l'aristocratie anglo-irlandaise à travers les changements du corps de Cuchulain et la récurrence croissante des présences spectrales. Bien que Cuchulain soit généralement considéré comme l'incarnation de l'identité nationale irlandaise et celle de l'aristocrate idéal dans les ouvres de Yeats, dans cet article j'envisage de mettre en lumière les endroits où ce mythe idéalisé de l'Irlande et de l'aristocratie est contesté par Yeats.

Mots clés: W. B. Yeats, aristocratie anglo-irlandaise, Cuchulain, spectralité, inquiétante étrangeté, théâtre irlandais moderne, héroïsme, joie tragique, regard.

The well-known Irish warrior-hero, Cuchulain, is most commonly mentioned in relation to Irish history and national identity, as an icon for the leaders of the Easter Rising. He is also referred to as Yeats's literary alter ego, anti-self or mask, as the Cuchulain plays reflect in many different ways Yeats's obsession with the most important women of his life, his life-long commitment to occult studies, his increasing disappointment in politics, and wish for cultural, individual, and natio- 
nal unity ${ }^{1}$. However, this paper wishes to elucidate that the figure of Cuchulain in Yeats's plays signifies much more than the mere embodiment of Ireland. Cuchulain is undoubtedly the embodiment of Yeats's heroic ideal, but Yeats's concept of heroism bears striking resemblance to his aristocratic ideal ${ }^{2}$. I will examine Yeats's Cuchulain primarily as the embodiment of Yeats's ideals of the Anglo-Irish aristocracy and the role this image assumed in his attempts to create a unified, independent Ireland at least in the mind's eye. More importantly, I also wish to point out those parts where this idealised narrative seems to be challenged.

Despite his glorification of the aristocracy, Yeats was also aware of the problems with this class and the limitations regarding their capacities to become the great ruling class of Ireland. As Marjorie Howes explains, "[h]e imagined the Anglo-Irish as a noble and worthwhile tradition, one capable of providing Ireland with the cultural continuity, political leadership and artistic integrity that he thought middle-class Catholic Ireland lacked. However, he also imagined AngloIrishness as a nationality founded on crime, perpetually in crisis and inherently subject to degeneration and decay". This major ambiguity of Yeats's life and work manifests itself in many aspects of his depiction of Cuchulain's body and the effects of the omnipresent spectral figures on the changes of his body. I will apply the term "spectral" to those uncanny presences which threaten and shake the protagonist's bodily integrity by means of their tragic laugh, sinister gaze, or otherworldly cry. These spectral figures will generate fear and awe, repulsion and attraction in Cuchulain whom they are chasing. Seamus Heaney also refers to this phenomenon in Yeats observing that " $[\mathrm{t}]$ he prospect of devastation excited as well as distressed him ${ }^{4}$ ". These spectral figures appear in human form yet they are capable of changing shape, and mediate between the terrestrial and supernatural worlds, representing a kind of Freudian uncanny. Through the five plays, Cuchulain is sometimes portrayed as a strong, vigorous, undefeatable figure full of bright prospects and hopes, while in other instants, he is presented as a weakened, vulnerable character gradually losing his physical strength and turning into a spectral image. Thus his superior qualities and greatness include a necessary decay and inevitable fall. I propose that this shifting between embodiment and disembodiment serves to express Yeats's ambiguity over the capacities of his

1. For an insightful analysis of how the Cuchulain plays correspond to the crucial events in Yeats's life see Birgit Bjersby's monograph The Interpretation of the Cuchulain Legend in the Works of W. B. Yeats, Uppsala, Lundequist, 1950 and Brendan Kennelly's article "The Heroic Ideal in Yeats's Cuchulain plays", Hermathena, No. 101, Yeats Number (Autumn 1965).

2. B. Kennelly, "The Heroic Ideal in Yeats's Cuchulain plays", op. cit., p. 13.

3. Marjorie Howes, Yeats's Nations: Gender, Class, and Irishness, Cambridge, Cambridge University Press, 1999, p. 103.

4. Seamus Heaney quoted in Anthony Bradley, Imagining Ireland in the Poems and Plays of W. B. Yeats: Nation, Class, and State, New York, Palgrave Macmillan, 2011, p. 105. 
otherwise idealised aristocracy and thus includes a considerable extent of irony as well. I also argue that the uncanny spectral figures of the plays represent a threat to Cuchulain's bodily strength and bring about the gradual disintegration of his physical existence, yet through the loss of his body they bring him closer to spiritual freedom. It is also important to note here that Yeats saw a very powerful relation between spirituality and the achievement of a nation's cultural unity. As R. F. Foster explains, Yeats thought that "unity of culture could be achieved by a nation that eschewed materialism in favour of spirituality". Through the sinister spectral figures and the spectralisation of Cuchulain's body, Yeats, to some extent, challenges his own narrative of an ideal aristocracy, shifting constantly between idealisation and ironisation of Cuchulain as the embodiment of Ireland - an ambiguity which is of crucial significance to the understanding of Yeats's works. The plays discussed include On Baile's Strand (1904), The Green Helmet (1910), At the Hawk's Well (1917), The Only Jealousy of Emer (1919), and The Death of Cuchulain (1939) ${ }^{6}$. In order to highlight the changes of Cuchulain's body, I will examine the plays not in the chronology of their composition but that of the original Cuchulain-legend starting with $A H W$ (Yeats's own addition to the Cuchulain-saga), and followed by $G H, O B S, O J E$, and $D C$.

Judith Butler writes in relation to the role of the body that it "is understood to be an active process of embodying certain cultural and historical possibilities $^{7}$. In these five plays, Cuchulain is supposed to represent the possibilities of the aristocracy in Ireland's cultural development and its decolonising movement. As Birgit Bjersby articulates it, "Cuchulain is the hero in whom Yeats incarnates his own fight for the intellectual freedom of his country and his own heroic-aristocratic view of life ${ }^{8 "}$. Yeats created a myth of the aristocracy and of himself too as being a representative of the Anglo-Irish intellectual nobility. The reason why Yeats could build up an aristocratic myth of himself was his father John Butler Yeats's family background (the Butlers' links to the Norman dynasty of the Dukes of Ormonde). The Butlers were related to the old Ascendancy, but it was a nobility already in decline, and with the marriage of Mary Butler and the Dublin merchant Benjamin William Yeats, the purity of the aristocratic past started to diminish'. This also means that Yeats was, to some extent, preoccupied with the idea of the inherent decline of the Protestant Ascendancy in his earlier works as well in which he seemed to propose an idealistic view of Ireland frequently using heroic

\footnotetext{
5. R. F. Foster, W. B. Yeats: A Life II: The Arch-Poet, New York, Oxford University Press, 2003, p. 178.

6. In this paper, I am going to use the following abbreviations for Yeats's plays: $O B S, G H, A H W, O J E$, and $D C$.

7. Quoted in Colette Conroy, Theatre \& the Body, Theatre \& Series, Jen Harvie and Dan Rebellato (eds), London, Palgrave Macmillan, 2010, p. 57.

8. Birgit Bjersby, The Interpretation of the Cuchulain Legend in the Works of W. B. Yeats, op. cit., p. 106.

9. Cf. R. F. Foster, W. B. Yeats: A Life I: The Apprentice Mage, New York, Oxford University Press, 1997, p. 1-5.
} 
figures from Celtic mythology. Parallel to Yeats's controversial ideas of the Ascendancy, he increasingly despised the bourgeoisie, which is relevant with regard to Yeats's representation of the spectral world in the plays. These Cuchulain plays will dramatise Yeats's fear of the disappearance of ancient aristocratic values from modern Ireland as a result of the self-indulgence and powerlessness of the modern Anglo-Irish aristocracy and the increasing power of the middle-class. These preoccupations are nicely summarised by Yeats's friend Lady Dorothy Wellesley: "By aristocracy he [Yeats] meant the proud, the heroic mind. This included a furious attitude towards the cheap, the trashy, the ill-made. And he certainly deplored the passing of the stately homes, and the gradual effacement of the well or highly born $^{10}$ ". During his lifetime, Yeats witnessed the decline and decease of those prominent figures who had symbolised for him the nobility of the mind and the Ascendancy spirit: Charles Stuart Parnell passed away in 1891, John Millington Synge in 1909, Major Robert Gregory in 1918 and Robert Gregory's mother Lady Augusta Gregory in 1932. The disappearance of aristocratic spirit and intellectual nobility symbolised by the death of these people can be seen dramatised in the Cuchulain cycle where the ubiquity of insubstantial, disturbing figures arising from an unknown realm aims to erase certainty, familiarity, and thus questions or rethinks the feasibility of existing myths of Ireland and its Ascendancy.

What the spectral presences do to Cuchulain in these plays is destroy of his body and immortalise his soul. This is a process initiated by the otherworldly hawk-cry and penetrating gaze of the Guardian of the Well in $A H W$ (1917). As Erika Fischer-Lichte states, "[t]he close relationship between body and voice is especially evident in screams, sighs, moans, sobs, and laughter. These utterances are unmistakably created through a process that affects the whole body: the body doubles over, contorts, and enlarges [...]. The screaming, sobbing, or laughing voice penetrates the bodies of the listeners, echoes in and is absorbed by their bodies ${ }^{11}$ ". This is what the hawk-woman's cry does to Cuchulain and the Old Man's body in the play. As Pierre Longuenesse points out, this woman is a disguised figure suggesting a hawk. She has a human body, but what makes her spectral is that a spirit cries from within her body, and that shade has the cry of a hawk ${ }^{12}$. As the Old Man puts it, "[i]t was her mouth, and yet not she, that cried./ It was that shadow cried behind her mouth ${ }^{13}$ ". She is, therefore, a channel through which the invisible world, the realm of the Sidhe, can speak to and threa-

10. Dorothy Wellesley quoted in B. Bjersby, op. cit., p. 100-101.

11. Erika Fischer-Lichte, The Routledge Introduction to Theatre and Performance Studies, Minjou Arjomand and Ramona Mosse (eds), London and New York, Routledge, 2014, p. 35.

12. Pierre Longuenesse, "'Singing Amid Uncertainty': Dramaturgie et pratique de la voix dans le théâtre de William Butler Yeats”, Doctoral Dissertation, Université de Paris-Sorbonne, 2008, p. 177. My translation.

13. W. B. Yeats, The Collected Plays of W. B. Yeats, London, Papermac, 1982, p. 215. 
ten the living. It is significant that her possessed body is shivering too, as it is under the influence and control of an invisible spirit: "Look at her shivering now, the terrible life/Is slipping through her veins. She is possessed ${ }^{14}$."

Her role as a mediator between two realms is also nicely indicated in the text by the separation of her voice from her body ${ }^{15}$. This disruption evokes the Freudian concept of the uncanny, which appears in each of the Cuchulain plays in various forms and in each case the aim of the uncanny spectral figures is to precipitate Cuchulain's loss of body, failure and journey towards an invisible realm ironically presented as the only place where unity is available for the hero's soul. As Colette Conroy puts it, "Freud suggests that uncanniness is a physical response to a disturbance of expectations about the human body and human capacity ${ }^{16}$. She continues that " $[\mathrm{t}]$ he notion that suddenly our habitual ways of reading the body don't work, or a body that changes our expectations about its capacity or appearance produces in the spectator a distinctive thrill of horror ${ }^{17}$ ". When Cuchulain faces this figure, he cannot define what he sees exactly: a bird, a woman, or a witch. He hears the hawk-cry but cannot see the bird. This lack of knowledge horrifies him, yet at the same time attracts him: "Do what you will, I shall not leave this place/Till I have grown immortal like yourself ${ }^{18}$." The word "horror" is also crucial because one of the basic characteristics of Yeatsian heroes is the tragic joy that surrounds their actions and eventual failure or triumph. As Otto Bohlmann explains, "[b]oth he and Nietzsche regard tragedy as providing the metaphysical comfort that beneath the whirl of phenomena eternal life flows on indestructibly ${ }^{19}$ ". Hence "Yeatsian tragedy promotes exultation in the midst of terror ${ }^{20 "}$. Yeats's obsession with this idea can equally originate in the disturbing ambiguity of the Anglo-Irish aristocracy as both great, intellectually superior and at the same time tragic, degenerating, and marked with acts of crime.

The play expresses this ambiguity also through the representation of Cuchulain and the Old Man as antithetical counterparts. The Old Man has already gone through a kind of bodily decay and seems pessimistic about his dream of reaching immortality, although he has not given up yet. In contrast, the young Cuchulain is very self-assertive, strong, and is ready to face any kind of obstacle. In Yeats's works, in fact, this constant element of hope and heroic ambition is what makes a

14. Ibid., p. 215.

15. For a detailed analysis of this theme see Pierre Longuenesse's doctoral dissertation quoted above.

16. Colette Conroy, Theatre \& the Body, op. cit., p. 26.

17. Ibid., p. 27.

18. W. B. Yeats, The Collected Plays of W. B. Yeats, op. cit., p. 215.

19. Otto Bohlmann, Yeats and Nietzsche: An Exploration of Major Nietzschean Echoes in the Writings of William Butler Yeats, London, Macmillan, 1982, p. 53.

20. Otto Bohlmann, Yeats and Nietzsche: An Exploration of Major Nietzschean Echoes in the Writings of William Butler Yeats, London, op. cit., p. 54. 
hero even if he/she is defeated. As Kennelly has it, "[f]or the hero, immortality is found, not in a lifetime of secure mediocrity, but in one of brief and self-assertive brilliance ${ }^{21}$ ". Through the stark contrast between the Old Man and Cuchulain, Yeats both creates and questions the feasibility of his heroic and aristocratic ideal. One of the underlying reasons for this can be Yeats's reaction to the 1916 Rising: after Easter 1916, he often questioned the worth of the heroic sacrifice of those who died for Ireland, but at the same time he increasingly regarded the leaders as martyrs and heroes who became national symbols, just like Cuchulain.

In $A H W$, the hawk-woman's eyes also play a central role in the changes of Cuchulain's body. Even though her eyes are described as heavy and worn-out, they still have power, they can mesmerise. Her body and her eyes are deathless yet they can bring about the death of the body of their spectacle; her gaze initiates the disembodiment of Cuchulain. The Old Man explains, "[t]here falls a curse/On all who have gazed in her unmoistened eyes;/So get you gone while you have that proud step/And confident voice, for not a man alive/Has so much luck that he can play with $\mathrm{it}^{22}$ ". The Old Man continues that her gaze threatens mainly " $\left.\mathrm{t}\right]$ hose that have long to live ${ }^{23 "}$ and he suggests that any kind of encounter with her will curse the young warrior: "Or it may be that she will kill your children, $/[\ldots]$ / Or you will be so maddened that you kill them/With your own hand ${ }^{24 "}$ ". With this, the Old Man foreshadows the role of the hawk-woman's gaze on Cuchulain's fate: "Ah, you have looked at her;/She has felt your gaze and turned her eyes on us;/I cannot bear her eyes, they are not of this world,/Nor moist, nor faltering; they are no girl's eyes 25 ". Her eyes appear to be as a kind of medium between the visible and invisible worlds, which try to pull Cuchulain into their own spectral realm by destroying his bodily integrity.

$G H$ (1910) offers a very bitter and pessimistic portrayal of Ireland, presenting it as a land characterised by confusion, inner conflicts, shame and disgrace. This bitterness can be traced back partly to Yeats's reaction to the death of Synge in 1909, who had represented for Yeats one type of his ideal Irishmen (the solitary, imaginative countryman possessing intellectual nobility). As Kennelly explains, "Synge had enriched Ireland by expressing it; [but] Ireland had rejected Synge ${ }^{26 "}$. This is why despite the scathing criticism of Ireland expressed in the play, it eventually concludes with the celebration of Cuchulain's intellectual nobility and wisdom that save the house and, symbolically speaking, Ireland. However, as arti-

21. B. Kennelly, "The Heroic Ideal in Yeats's Cuchulain plays", op. cit., p. 18.

22. W. B. Yeats, The Collected Plays of W. B. Yeats, op. cit., p. 215.

23. Ibid., p. 215.

24. Ibid.

25. Ibid., p. 216.

26. B. Kennelly, "The Heroic Ideal in Yeats's Cuchulain plays", op. cit., p. 15. 
culated in Yeats's "The Fisherman" (1919), such men are but a dream, yet Yeats still goes on creating a myth of an ideal Irishman and an ideal Ireland.

The noblemen's (Laegaire and Conall's) fallen house is threatened by two spectral figures in this play, the Red Man and the Black Man, but it is the Red Man whose role is the most crucial. Even though the Red Man seems to appear as a physical presence in front of the court, the dramatis personae indicate that he is a spirit. Thus, once again, we have a mediator between the visible and invisible realms. Here Cuchulain is a palpable, virile figure full of bodily and spiritual strength, his body is compared to the sun, and he has grown in wisdom as well. Conall makes it clear that he is more than a human being, and there is something mysterious about him as if he were a half-immortal figure, an ideal mediator between the two realms: "I thought no living man could have pushed me from the door ${ }^{27 "}$. More importantly, Laegaire and Conall still believe that such a great figure as Cuchulain could stop the degeneration of their house: "He was born to luck in the cradle, his good luck may amend/The bad luck we were born to $^{28}$." The central conflict of the play is brought about by the Red Man, who challenges the noblemen of the house, asking one of them to whip off his head and afterwards, allowing him (the Red Man) to cut off his opponent's head as well, thus offering a "head for head" game. If it were not for Cuchulain, the Red Man could precipitate and intensify the fall and disgrace of the house, but Cuchulain's bravery saves them. The game proposed by the Red Man is in itself a game about the disintegration and re-integration of the body, which suggests the whole structural pattern of the Cuchulain cycle and the fate of Cuchulain's body. Laegaire and Conall describe the Red Man as an intruder, a stranger and a "wide, high man [who] came in with a red foxy cloak,/ With half-shut foxy eyes and a great laughing mouth ${ }^{29 "}$. The noblemen of the house are ambushed by the disturbing strangeness of this figure and they do not understand why he "laughs like the sea $^{30 "}$, why he mocks them and looks at them so threateningly. Just as the hawkwoman's cry and mesmerising eyes in $A H W$, the Red Man's foxy eyes and sinister laughter penetrate the bodies of the living and thus shake Cuchulain's bodily integrity as well.

The Red Man's demonic laughter similarly permeates and disturbs Cuchulain's and the others' bodies, because such a joyful, triumphant laughter is not compatible with the tragic circumstances of the game proposed by the Red Man - they do not understand what is going on, what it means, and this lack of comprehension, the fear of the unknown, contribute to the uncanny nature of this scene.

27. W. B. Yeats, The Collected Plays of W. B. Yeats, op. cit., p. 226.

28. Ibid., p. 228.

29. Ibid.

30. Ibid., p. 231. 
Conroy mentions with regard to the uncanny that it is always "the feeling that something is disturbingly not quite right, that it is not understood fully, that is may or may not have subjectivity ${ }^{31}$ ". Among her examples, she lists the presence of severed heads, unmotivated laughter, and demonic possessions, all of which occur at various parts of the Cuchulain cycle and always affect Cuchulain's physical strength. At the end of the play, for instance, Cuchulain voluntarily offers the disintegration of his body (the cutting of his head) to the Red Man - a self-sacrifice and bravery which in this play help him to save and maintain his bodily integrity and celebrate him as the most ideal man to represent Ireland. As Kennelly observes, "it is precisely this calm willingness to honour the debt through selfimmolation that establishes Cuchulain in heroic superiority ${ }^{32 "}$. What is more, " $[t]$ he Red Man [...] had consciously created chaos so as to discover somebody who could impose order on it [...] Only Cuchulain completely fulfils this image, and only he deserves the appropriate immortality 33 ".

OBS (1904), however, puts an end to these idealisations and illustrates a radical change both in the cycle and in the idea of Cuchulain as the perfect embodiment of Ireland. It has to be noted that in the years of the composition of this play (1903 and 1904), Yeats was still under the influence of the nationalist Fenian tradition of John O'Leary, because for Yeats Fenianism carried the aura of the heroic past and ancient nobility of which Cuchulain was a perfect example. However, these were also the years when he began to turn his back on radical nationalist politics and express his support for Home Rule ${ }^{34}$. In $O B S$, we can map the traces of this process of change in Yeats's political views as well as his growing hesitations, for one of the main themes of this play is the effect of compromise on Cuchulain. Cuchulain's heroic-warrior spirit is tamed in this play, but, as Kennelly points out, "the play's conclusion shows that, for a hero, compromise is disaster ${ }^{35}$ ".

The play also dramatises Cuchulain's disappearance from the terrestrial, visible world: after the tragic realisation that he has killed his own son, he starts fighting the waves (believing that the sea is the High King Conchubar whom he blames for the tragedy), and his body is absorbed by the deathless sea. Yet he does not die, he simply transcends into the invisible realm - an event presented by the other characters as something tragic and fatal. Cuchulain's body begins trembling in the moment when he realises he has fallen prey to a kind of witchcraft. The trembling of his body shakes the bench on which he is sitting with the Fool and the Blind Man. The process of Cuchulain's leaving the closed and limited space of the

31. Colette Conroy, Theatre \& the Body, op. cit., p. 26.

32. B. Kennelly, "The Heroic Ideal in Yeats's Cuchulain plays", op. cit., p. 16.

33. Ibid.

34. Roy Foster, W. B. Yeats: A Life I, p. 340-341.

35. B. Kennelly, "The Heroic Ideal in Yeat's' Cuchulain plays", op. cit., p. 15. 
house and his approaching the waves is emphasised by the Blind Man who tells the raging and trembling Cuchulain that he will find Conchubar " $[\mathrm{b}]$ etween the door and the sea ${ }^{36 "}$, as if pointing out the path between two worlds. But it is only from OJE (1919) that we know that the waves of the sea are indeed an entrance to the spectral world. As Emer tells the story to Eithne Inguba, she refers to the sea with the adjective "deathless", in the same way as the hawk-woman and the Red Man are alluded to. Also, she makes it clear that the waves did not kill her husband, but made an image out of his body ${ }^{37}$.

The sinister spectral presences occur in this play as well. Here the maker of discord is Cuchulain's own son sent over from Scotland by Aoife, Cuchulain's former lover, a woman of the mountains as already mentioned in $A H W$. He very much resembles his mother and therefore to some extent Aoife is mirrored in the boy: "His head is like a woman's head (I had fancy for) ${ }^{38 "}$ ". He has clear eyes "burning nearer up in the high air $^{39}$ ". Even though Aoife is referred to as a fleshand-blood woman who gave birth to Cuchulain's son, she too can be labelled as a spectral presence here. She is both present and absent throughout the five plays: her name and extraordinary qualities are mentioned in each play; her aim is to kill Cuchulain; she has an invisible, disturbing, threatening presence everywhere, yet she is physically absent, and appears only in the last play. Thus it seems that here it is her eyes that look at Cuchulain through the son. It appears that the penetrating eyes of the hawk-woman have followed Cuchulain through the foxy eyes of the Red Man until the clear but cold eyes of his own son which reflect Aoife's eyes and which will stare at Cuchulain in the last play as well fully possessing his body by then. In fact, it is Aoife who threatens Cuchulain through the spectral, unsettling figures in each play, and this is foreshadowed by the Old Man of $A H W$ : "She [the hawk-woman] has roused up the fierce women of the hills,/Aoife, and all her troop, to take your life,/And never till you are lying in the earth/Can you know rest $^{40}{ }^{\prime \prime}$. Aoife's invisible body is present in $O B S$ as well, but it is only at the end of the play that Conchubar mentions the possible presence of an insubstantial figure above them: "Some witch of the air has troubled Cuchulain's mind ${ }^{41}$ ". And he soon repeats: "Some witch is floating in the air above us ${ }^{42}$ ". This is Aoife's unsettling ubiquity in the play, as simultaneously with Conchubar's warnings, Cuchulain recognises the familiarity in the disturbing appearance of the young stranger.

36. W. B. Yeats, The Collected Plays of W. B. Yeats, op. cit., p. 277.

37. Ibid., p. 284.

38. Ibid., p. 268.

39. Ibid., p. 265.

40. Ibid., p. 218.

41. Ibid., p. 268.

42. Ibid., p. 270. 
OJE (1919) dramatises the shift from Cuchulain's disembodied presence to a weakened embodiment, very different from the one depicted in $A H W$ and $G H$. The gradual disappearance of Cuchulain as a heroic figure in this play can be seen as a reflection of the violence that surrounded the Anglo-Irish from 1919 on during the Anglo-Irish War, when nationalist IRA forces attacked the Ascendancy and destroyed many significant Big Houses. What is more, Major Robert Gregory passed away in 1918: Yeats thought that Lady Gregory's son Robert Gregory epitomised the values of the ideal hero as well as those of the spiritual aristocracy. Yeats lamented his death as a foreboding sign for Ireland's fight for cultural and political unity, but he glorified Robert Gregory in his poems as a hero who found joy in his tragedy, thus making him a model for his ideal hero similar to the figure of Cuchulain.

OJE presents Cuchulain's bodily weakening through the tripling of his spectral body: we have the Ghost of Cuchulain, the Figure of Cuchulain (both wearing heroic masks), and Bricriu, Cuchulain's mask, who convinces Emer to renounce her husband's love. And there is another spectral figure: Fand, the Woman of the Sidhe. This woman is equal to the hawk-woman of the first play: "You were not so dumbfounded when/I was that bird of prey, and yet/I am all woman now ${ }^{43}$." She tempts Cuchulain promising him completion (knowledge and unity) as soon as he chooses her. It is implied that the invisible realm is the only sphere where the Unity of Being is available. This unity could have been reached by Cuchulain if he had kissed Fand - an act that would have purified him of memory and would have given him a superior knowledge - yet ironically it is Emer (his other self) and through her Bricriu, his own mask, that prevent him from fully achieving that superhuman sphere.

The gaze, again, plays a central role in this re-embodiment process. But here, the most important gaze is that of the living (Emer), and its aim is to restore Cuchulain's body weakened and reduced to an image by the gaze of the spectral figures. Bricriu's major role in the play is to give sight to Emer and thus knowledge. When Emer attempts to kill the Woman of the Sidhe, he states: "No knife/Can wound that body of air. Be silent; listen; / I have not given you eyes and ears for nothing 44 ". As Alexandra Poulain observes "Cuchulain only comes alive when Emer constitutes herself as a spectator to watch him ${ }^{45}$ ". Initially, Emer cannot see Cuchulain - it is Bricriu who "makes the invisible visible, thus asserting the coexistence of several strata of reality ${ }^{46 "}$. Thus while the gaze of the

\footnotetext{
43. Ibid., p. 292.

44. Ibid., p. 291.

45. Alexandra Poulain, “Westward ho!': The Only Jealousy of Emer, From Noh to Tragedy”, The South Carolina Review, Vol. 43. No. 1, Catherine E. Paul (ed.), Fall 2010, p. 94.

46. Alexandra Poulain, “'Westward ho!': The Only Jealousy of Emer, From Noh to Tragedy”, op. cit., p. 95.
} 
uncanny spectral figures of the previous plays aims to deconstruct Cuchulain's physicality, Emer's gaze reconstructs the body. To put it more accurately, the spectral figures' gaze dematerialises the body, while the living figures' eyes are capable of rematerialising it. This also invokes Jean-Paul Sartre's ideas of the distinction between the look and the gaze referred to as the regard. Sartre in his Being and Nothingness provides the example of a voyeur peering through the keyhole of a door, totally full of himself, absorbed in his spectacle, almost entirely devoid of self-consciousness (like Cuchulain at the end of $O B S$ when he sees nothing but the waves). However, when he suddenly notices that someone (the so-called 'Other') is approaching watching him, he has to reconstitute himself from nothingness into a new kind of subjectivity. It is a process of decentralisation: by acknowledging that he is no longer the bearer of the look but the spectacle of another voyeur, he turns from master to slave ${ }^{47}$. Also, as Kaja Silverman epitomises, in Sartre's view "[t]o function as a spectacle, and so to exist for the Other, is to lapse into a 'fallen' state ${ }^{48}$ ". Even though Cuchulain recovers his physical existence thanks to Emer, this is a new kind of subjectivity; he has gone through a decentralising process. It is true that even before the fight with the waves Cuchulain constantly felt the gaze of spectral presences on his body, but this shift from watching to being watched appears most visibly when Cuchulain becomes absorbed in the spectacle of the waves, disappears into nothingness, and comes alive again when he feels Emer's eyes watching him. This journey from spectator to spectacle indicates a decentralised, fallen state of Cuchulain.

Through the five plays, therefore, Cuchulain's shifting between embodiment and disembodiment is also indicated by his constant vacillation between spectator and spectacle, which is an important element in Yeats's idiosyncratic dramaturgy in general. Longuenesse elucidates that the dynamics of Yeats's dramaturgy are based on a permanent tension between the real world of the living and the realm of the spectral figures that constantly haunt and threaten the living ${ }^{49}$. He explains that this tension is achieved by the presence of spectator-characters listening to the sounds coming from unknown sources (they are onstage, trying to decode the meaning of the noises coming from offstage) and the disturbing reality of those (mainly spectral) figures who are listened to; and finally the audience-asspectator who can often see the appearance of those figures whom the living characters cannot ${ }^{50}$. For instance, in $A H W$, Cuchulain and the Old Man are trying to decipher the meaning of the hawk-woman's penetrating gaze and her hawk-

47. Cf. Kaja Silverman, "The Look ", The Threshold of the Visible World, New York, Routledge, 1996, p. 64-66.

48. Kaja Silverman, "The Look", op. cit., p. 165.

49. Pierre Longuenesse, "'Singing Amid Uncertainty': Dramaturgie et pratique de la voix dans le théâtre de William Butler Yeats", op. cit., p. 167.

50. Ibid., p. 166-167. 
cry: "What are those cries?/What is that sound that runs along the hill ${ }^{51}$ ?" In $G H$ Cuchulain and the other noblemen endeavour to interpret the meaning and the sense behind the Red Man's disturbing game and laughter. In $O B S$, the same waiting for and listening to the unexpected arrival of a stranger from the outside happen when Cuchulain and Conchubar try to find out who the Young Man is and where he comes from and why. In OJE it is Emer and Eithne Inguba who listen carefully to the possible signs from Cuchulain's half-dead body and then to the disturbing words of Cuchulain's mask (or spectral double) Bricriu and they try to decode the Woman of the Sidhe's intention with Cuchulain's body. Finally, in $D C$ the increasingly weakening hero is waiting for his death which arrives in the form of Aoife first, then in the grotesque figure of the Blind Man of OBS. While Cuchulain is dying, he and Eithne Inguba try to make sense of the foreboding presence of the crow-headed goddess of war, the Morrigu.

However, it is striking that in each of these plays, there are moments when Cuchulain is not a spectator or a listener, but a spectacle and the one who is observed. The first three plays of the cycle begin with other characters' conversation suddenly disturbed by the arrival of Cuchulain seen initially as a stranger. He too arrives from an unknown place and perturbs the peace of the others just like the spectral figures unsettle Cuchulain's peace of mind and bodily integrity. In $O J E$, he is clearly reduced to a motionless spectacle, a mere image that cannot see nor hear, but can be an object of contemplation. Everyone is waiting for him to say something or move, which finally happens, but his spectator status is not restored. In the last play, he is totally subject to the others' scrutinising observations. His bodily weakening is constantly reflected on by Eithne Inguba, Aoife, the Morrigu, and the Blind Man. Cuchulain has gone through a process of decentralisation, he has lost all control over his body and his world. This is why he warns Eithne Inguba, "[s]peak low if you would speak about my death,/Or not in that strange voice exulting in it./Who knows what ears listen behind the

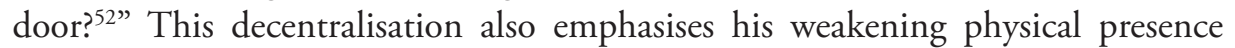
and the expansion of the spectral world, increasingly absorbing the world of the living. Longuenesse points out that the predominance of spectral bodies in Yeats's theatre precipitates the erasure of the character through the protagonist's attempts to decipher the sounds and voices coming from the unsettling spectral realm ${ }^{53}$. This is how the spectral world gradually consumes and begins to possess Cuchulain. Poulain calls attention to another important aspect of Yeats's dramaturgy in her article on The King's Threshold, Calvary and The Death of Cuchulain, which is

51. W. B. Yeats, The Collected Plays of W. B. Yeats, op. cit., p. 218.

52. Ibid., p. 697.

53. Pierre Longuenesse, "'Singing Amid Uncertainty': Dramaturgie et pratique de la voix dans le théâtre de William Butler Yeats", op. cit., p. 169. 
crucial if applied to the Cuchulain cycle: "Ultimately what the plays attempt to dramatise is what befalls the subject when the subject ceases to be ${ }^{54}$. Bearing in mind Cuchulain's status as an alternative symbol of Ireland and the Ascendancy (as well as Yeats's own origins), Cuchulain's physical disappearance raises the more concrete question of what happens to modern Ireland when the intellectual, aristocratic individual and its values disappear forever.

In $D C$ (1939), the hero accepts his bodily weakening and imminent death, which seems to echo Yeats's elitist preoccupations expressed in his 1939 On the Boiler: "[ $\mathrm{t}]$ he danger is that there will be no war, that the skilled will attempt nothing, that the European civilisation [...] will accept decay55". By this time, Yeats became disappointed in most of his formerly promoted political ideals. As Anthony Bradley explains it, "Yeats knew, then, that the Ireland he had long ago imagined and idealized as noble and heroic had plunged into the kind of political violence and instability that was widespread in Europe, $[\ldots]$ and that he lived in a period in which the continuum of history had paused, and was about to be reset $^{56 "}$. Yet when he met Maud Gonne for the last time, he evoked their nationalist past and the image of the Castle of Heroes that used to symbolise independent Ireland for the members of the Celtic Mystical Order (the ex-Golden Dawners like Yeats and Gonne): "Maud, we should have gone on with our Castle of the Heroes, we might still do it $^{57}$." We can see that Yeats, even at his most desperate and pessimistic, maintained a little hope for the realisation of his dreams about modern Ireland, and it is this shifting between bitterness and optimism that occurs in each Cuchulain play.

$D C$ also nicely illustrates this shifting attitude to Ireland's future. The uncanny spectral world (Aoife and the Morrigu) starts to gradually dominate the play and Cuchulain: Eithne Inguba tells Cuchulain that "I know that somebody or

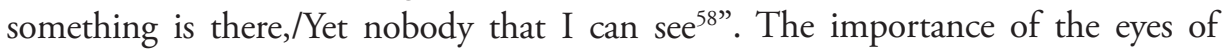
the spectral figure returns: "She [the Morrigu] seemed as pretty as a bird, she has changed,/She has an eye in the middle of her forehead 59 ." Now this bird-like woman with the penetrating eyes catches Cuchulain once more after the death of his physical body. Right before the moment of his death, he still has a strong physical presence (though his body is already weak), as the beggar "begins feeling Cuchulain's

54. Alexandra Poulain, "The King's Threshold, Calvary, and The Death of Cuchulain: Yeats's Passion Plays ", Yeats's Mask: Yeats Annual No. 19, Margaret Mills Harper and Warwick Gould (eds), Cambridge, UK, Open Book Publishers, 2013, p. 60. [http://dx.doi.org/10.11647/OBP.0038]

55. W. B. Yeats, On the Boiler, Dublin, Cuala Press, 1939, p. 19. Web. 28 December 2016 [http://nla.gov.au/nla. obj-50578018].

56. Anthony Bradley, Imagining Ireland in the Poems and Plays of W. B. Yeats: Nation, Class, and State, op. cit., p. 105.

57. W. B. Yeats quoted in Michael Manning, W. B. Yeats Seanad Eireann Speeches 1922-28. Lulu Press, 2015, p. 48.

58. W. B. Yeats, The Collected Plays of W. B. Yeats, op. cit., p. 696.

59. Ibid., p. 696. 
body, his hands mounting upward ${ }^{60}$ and finally cuts off his head. This image is followed by a transformation: even though Cuchulain loses his body, he manages to transform into "[his] soul's first shape, a soft feathery shape ${ }^{61}$ ". This description suggests the hawk (constantly associated with Cuchulain in the cycle) and through this proud and noble bird (the symbol of the aristocracy) it refers to the superhuman, highest sphere of existence as well. It means that Cuchulain's soul seems to have eventually achieved immortality through the sinister influence of the uncanny spectral figures. Cuchulain dies but he is able to show intellectual ecstasy even in the face of death, and this evokes Yeats's remark to Ethel Mannin towards the end of his life: "It is a curious experience to have an infirm body $\&$ an intellect more alive than it has ever been ${ }^{62}$." Yet we need to keep in mind that Yeats's Cuchulain has always been a symbol, which means that this figure has little to do with the reality of modern Ireland. It is only in the mind's eye that this heroic and aristocratic myth of Ireland can be fully realised.

After this transformation, we see Emer dancing before Cuchulain's severed head: "She so moves that she seems to rage against the heads of those that had wounded Cuchulain [...]. She moves as if in adoration or triumph round the head of Cuchulain ${ }^{63}$." This is a joy in terror which is an indispensable characteristic of Yeats's concept of heroism. He has to lose his physicality, his body and everything that ties him to the terrestrial world in order to reach immortality and the Unity of Being. However, it remains ambiguous whether this transformation is to be regarded as tragic or joyful. It is undoubtedly ironical that all this implies that such a condition is not available in the visible world, yet heroes such as Cuchulain and the martyrs of the Easter Rising (compared to Cuchulain in the play) must always attempt to reach the highest sphere even though it means the death of their bodies. This is what makes Yeats's heroes outstanding and ideal ${ }^{64}$. This effort to aim high despite the evident failure and death is exactly what finally elevates them to the highest sphere of being, even though they cease to exist in their physical reality. As the Musicians sing in $A H W$ as if uttering Cuchulain's thoughts: "Folly alone I cherish,/I choose it for my share;/Being but a mouthful of air,/I am content to perish;/I am but a mouthful of sweet air ${ }^{65}$."

60. Ibid., p. 702.

61. Ibid.

62. W. B. Yeats qtd in Foster, W. B. Yeats: A Life II, p. 550.

63. W. B. Yeats, The Collected Plays of W. B. Yeats, op. cit., p. 703.

64. Carmel Jordan argues in her article that Yeats expresses the both tragic and extraordinary qualities of Ireland through the stone symbol in his Cuchulain plays, which is always associated with Cuchulain and the threatening spectral figures ("The Stone Symbol in 'Easter 1916' and the Cuchulain Plays", College Literature, 13. 1, 1986, p. 36-43).

65. W. B. Yeats, The Collected Plays of W. B. Yeats, op. cit., p. 219. 
Yeats's Cuchulain-cycle, therefore, appears as yet another example of Yeats's life-long obsession with the role of the aristocracy in the formation of a unified Ireland and the constant ambiguities that surrounded this myth. Yeats both constructs and deconstructs his heroic and aristocratic ideal in the cycle, expressing his wish to restore in modern Ireland those more ancient values which are already lost. As Suzan-Lori Parks has it, "the very act of playwriting is akin to digging for bones in a burial site, an act of loving excavation of the lost and forgotten $^{66}$." The whole cycle presents a constant shifting between Cuchulain as the saviour of Ireland and Cuchulain as the inherently degenerate figure who can do nothing but induce further decay in the country. This ambiguity occurs mainly through the role of the spectral figures that both threaten Cuchulain and help him to finally achieve spiritual immortality. As Mary Luckhurst and Emilie Morin have explained, "[t]he phantom's uncertain ontological status interrogates both what it is to see and what it is to know, and thereby provides a device for challenging theories of epistemology as well as the boundaries between life and death, the political elite and the oppressed, the rational and the irrational, the material and immaterial ${ }^{67 "}$.

66. Quoted in Mary Luckhurst and Emilie Morin, "Introduction: Theatre and Spectrality", Theatre and Ghosts: Materiality, Performance and Modernity, New York, Palgrave Macmillan, p. 15.

67. Mary Luckhurst, "Introduction: Theatre and Spectrality", op. cit., p. 2. 